\title{
PROBLEMATIKA DALAM PELAKSANAAN PEMUNGUTAN BEA PEROLEHAN HAK ATAS TANAH DAN BANGUNAN (BPHTB) DI KOTA PADANG*
}

\author{
Eka Susanti \\ Ikatan Notaris Indonesia, Padang \\ Jl. M. Hatta No. 51 Ketaping RT.003/RW.004, Kel. Pasar Ambacang, Kec. Kuranji, Padang \\ e-mail: ekasusanti085@gmail.com
}

\begin{abstract}
One type of tax is the Cost of Acquisition of Land and Building Rights (BPHTB). In Padang City, based on Regional Regulation Number 1 of 2011 and Regulation of Mayor Number 27 of 2016, the BPHTB tax collection system is different where the BPHTB collection system is not cohorence with the implementation of basic tasks and is determined by the parties as regulated by the function of increasing development activities in all fields. The research problems in this article are: 1) How is the collection of BPHTB in Padang City 2) How the verification process the land and building and constraints was receipts from land and building rights to the certificate of together in Padang City? 3) Are efforts of the government of padang in obstacles as receipts from land and building rights to the certificate of together in Padang City? The research uses empirical juridical research methods. Primary data and secondary data obtained through literature study and interviews with research subjects. The results shows that the implementation of BPHTB collection in Padang city was carried out based on the Mayor Regulation No. 27 of 2016 and there are differences in tax collection regulated by Regional Regulation Number 1 of 2011, namely in the Cost of Acquisition (NPOP) assessment and collection system based on market prices, not transaction prices regulated in Bylaw No. 1 of 2011. The differences create legal uncertainty for the community. The obstacle that arises in the collection of Padang city BPHTB is the lack of taxpayer knowledge about BPHTB.
\end{abstract}

Keywords : The Determination of Land And Building, APHB, BPHTB.

\section{Abstrak}

Salah satu jenis pajak adalah Bea Perolehan Hak Atas Tanah dan Bangunan (BPHTB). Khususnya di Kota Padang berdasarkan Perda Nomor 1 Tahun 2011 dan Perwako Nomor 27 Tahun 2016, sistem pemungutan pajak BPHTB berbeda dimana sistem pemungutan BPHTB tidak koheren dalam pelaksanaan tugas pokok dan ditentukan oleh para pihak sebagaimana diatur fungsi meningkatnya kegiatan pembangunan di segala bidang. Permasalahan dalam tesis ini yaitu 1) Bagaimana pemungutan BPHTB di Kota Padang, 2) Bagaimana proses verifikasi harga Tanah dan Bangunan serta kendala dalam Pemungutan BPHTB terhadap Pembuatan Akta Pembagian Hak Bersama (APHB) di Kota Padang ? 3) Apakah upaya Pemerintah Kota Padang dalam kendala Pemungutan BPHTB terhadap Pembuatan Akta Pembagian Hak Bersama (APHB) di Kota Padang? Penelitian ini dilakukan dengan metode penelitian yuridis empiris. Data Primer dan data sekunder diperoleh melalui Studi pustaka dan wawancara dengan subyek penelitian. Hasil penelitian menunjukkan bahwa pelaksanaan pemungutan BPHTB di kota Padang dilaksanakan berdasarkan Perwako Padang Nomor 27 tahun 2016, terdapat perbedaan pemungutan Pajak yang diatur oleh Perda Nomor 1 Tahun 2011, yaitu pada sistem pemungutan dam penilaian NPOP yang didasarkan pada harga pasar, bukan harga transaksi yang diatur dalam Perda Nomor 1 Tahun 2011. Perbedaan tersebut menimbulkan ketidakpastian hukum bagi masyarakat. Hambatan yang timbul dalam pemungutan BPHTB kota Padang yaitu kurangnya pengetahuan wajib pajak tentang BPHTB.

Kata Kunci: Penentuan Nilai Tanah dan Bangunan; APHB; BPHTB.

\footnotetext{
*Naskah diterima: 28 Februari 2020, direvisi: 19 Maret 2020, disetujui untuk terbit: 26 Maret 2019

Doi: $10.3376 /$ jch.v5i2.240
} 
Eka Susanti: Problematika Dalam Pelaksanaan Pemungutan Bea Perolehan Hak Atas...

\section{PENDAHULUAN}

Sistem perpajakan Indonesia, ada dua kelompok pajak terkait dengan lembaga yang berwenang memungut pajak, yaitu Pajak Pusat dan Pajak Daerah. Pembagian pajak ini terkait dengan hirarki pemerintahan yang berwenang menjalankan pemerintahan dan memungut sumber pendapatan/ penerimaan negara, khususnya pada masa otonomi daerah dewasa ini. (Marlon Gustia, 2016)

Pajak merupakan salah satu komponen penting dalam pembangunan di Indonesia karena sektor pajak di Indonesia merupakan sumber pendapatan terbesar bagi negara. Karena itulah pajak berperan penting bagi pelaksanaan pembangunan nasional. Tanpa ada masyarakat, tidak mungkin ada suatu pajak. (Rochmat Soemitro, 2004)

Pajak dan pemasukan negara yang bersifat memaksa sebagaimana yang dimaksudkan dalam Undang-Undang Dasar 1945 merupakan modal dan sumber pembiayaan bagi pembangunan negara. Oleh sebab itu mengenai hal ini harus mendapatkan pengaturan yang jelas dan dilaksanakan secara konsekuen serta diikuti dengan sanksi hukum yang mengikat dan memaksa untuk terjaminnya kelanjutan pembangunan nasional. (Eko Puji Hartono, 2018)

Meningkatnya kegiatan pembangunan di segala bidang, menyebabkan meningkatnya keperluan akan tersedianya tanah dan atau bangunan. Sedangkan tanah dan atau bangunan persediaannya sangat terbatas. Mengingat pentingnya tanah dan atau bangunan tersebut dalam kehidupan, maka sudah sewajarnya jika orang pribadi atau badan hukum yang mendapatkan nilai ekonomis serta manfaat dari tanah dan atau bangunan karena adanya perolehan hak atas tanah dan atau bangunan dikenakan pajak oleh negara. Salah satu jenis pajak yang sumber potensi pajak yang patut digali sesuai situasi dan kondisi perekonomian serta perkembangan pembangunan bangsa sekarang ini adalah jenis Pajak Bea Perolehan Hak Atas Tanah dan Bangunan (BPHTB). (Marihot Pahala Siahaan, 2003).

Bea Perolehan Hak Atas Tanah dan Bangunan (BPHTB) merupakan pajak yang dikenakan atas perolehan hak atas tanah dan atau bangunan. Perolehan Hak atas Tanah dan atau Bangunan adalah perbuatan atau peristiwa hukum yang mengakibatkan diperolehnya hak atas tanah dan atau bangunan oleh orang pribadi atau badan. Hak atas tanah adalah hak atas tanah termasuk hak pengelolaan, beserta bangunan di atasnya sebagaimana dalam Undang-Undang Nomor 5 Tahun 1960 tentang Peraturan Dasar PokokPokok Agraria dan peraturan perundangundangan yang berlaku. (Suryanto,2018)

Wirawan B. Ilyas dan Richard Burton mengatakan, bahwa objek Dari Bea Perolehan Hak Atas Tanah dan Bangunan (BPHTB) adalah perolehan hak atas tanah dan atau bangunan yang dapat berupa tanah (termasuk tanaman di atasnya), 
tanah dan bangunan, atau bangunan. (Wirawan B. Ilyas, 2004)

Seiring dengan pelaksanaan otonomi daerah, BPHTB yang sebelumnya dikelola oleh Pemerintah Pusat, berdasarkan Undang-Undang Nomor 28 Tahun 2009 tentang Pajak Daerah dan Retribusi Daerah (PDRD) dilimpahkan menjadi kewenangan Daerah (Pasal 180 angka 6 UU PDRD). Khusus mengenai BPHTB diatur dalam Pasal 85 sampai dengan Pasal 93. BPHTB telah resmi menjadi pajak daerah. Undang-Undang Nomor 28 Tahun 2009 menggantikan Undang-Undang Nomor 34 Tahun 2000. Perbedaan mendasar kedua undangundang tersebut adalah Undang-Undang Nomor 28 Tahun 2009 sifatnya limitatif sedangkan Undang-Undang Nomor 34 Tahun 2000 sifatnya enumeratif. (Budi Ispriyarso, 2018)

Pajak daerah adalah pungutan wajib atas orang pribadi atau Badan yang dilakukan oleh pemerintah daerah tanpa kontraprestasi secara langsung yang seimbang, yang dapat dipaksakan berdasarkan peraturan perundangundangan yang berlaku, yang digunakan untuk membiayai penyelenggaraan pemerintah daerah dan pembangunan daerah. Pajak daerah dibagi menjadi dua jenis, yaitu pajak Provinsi yang dikelola oleh pemerintah daerah tingkat Provinsi dan Pajak Kabupaten/Kota yang dikelola oleh pemerintah daerah tingkat Kabupaten/Kota. BPHTB merupakan satu dari sebelas jenis pajak daerah di tingkat Kabupaten/Kota. (Ilyas dan Burton, 2013)
Bea Perolehan Hak atas Tanah dan Bangunan (BPHTB) merupakan salah satu sumber penerimaan yang sangat potensial, Dinas Pendapatan Daerah berupaya mengelola secara maksimal guna meningkatkan Pendapatan Asli Daerah untuk menunjang pembangunan Daerah. Untuk meningkatkan Penerimaan Bea Perolehan Hak atas Tanah dan Bangunan realisasi harus melebihi target yang ditentukan sebelumnya. (Wa Ode Nurfitria, 2017)

Diberlakukannya Undang-Undang Nomor 28 Tahun 2009, ditentukan bahwa pengalihan kewenangan pemungutan BPHTB sebagai Pajak Kabupaten/Kota, dilaksanakan sepenuhnya oleh Kabupaten/Kota mulai 01 Januari 2010, maka pemungutan Pajak Daerah harus ditetapkan dengan Peraturan Daerah dan tidak berlaku surut. Penetapan Peraturan Daerah ini dimaksudkan agar Pemerintah Kabupaten/Kota dapat memungut BPHTB sesuai ketentuan Peraturan Perundangundangan. (Mahdi Syahbandir, 2016)

Pelaksanaan pemungutan BPHTB diindikasikan bahwa masih ada wajib pajak yang belum mengetahui pengenaan BPHTB atas perolehan atau peralihan tanah dan bangunan. Masyarakat cenderung mengetahui adanya pengenaan BPHTB atas perolehan atau peralihan hak atas tanah dan bangunan ini dari pihak Notaris/PPAT. Padahal dalam pemungutan BPHTB ini menganut self assesment system, dimana suatu system pemungutan pajak yang memberikan kepercayaan dan tanggung jawab kepada wajib pajak untuk menghitung, menyetor, 
Eka Susanti: Problematika Dalam Pelaksanaan Pemungutan Bea Perolehan Hak Atas...

dan melaporkan sendiri pajak terutang. Jika wajib pajak tidak mengetahui dasar dan ketentuan pengenaan BPHTB, wajib pajak tidak dapat menghitung sendiri BPHTB terutangnya. Kurangnya pemahaman masyarakat tentang BPHTB ini menjadi salah satu penghambat dalam pemungutan BPHTB. (Windy, 2015)

Kewajiban pajak merupakan kewajiban publik yang pribadi dan hal tersebut tidak dapat dialihkan kepada orang lain. Namun dalam hal sistem pemungutan pajak yang menggunakan sistem self assessment maka pajak dapat dikuasakan, oleh karena itu wajib pajak dapat meminta bantuan atau memberi kuasa kepada orang lain akan tetapi kewajiban tetap melekat pada dirinya dan wajib pajak berhak bertanggungjawab walaupun orang lain yang ditunjuk olehnya dapat ikut mempertanggungjawabkan. (Intifada Atin Nisya, 2019)

Pemerintah Daerah khususnya Kota Padang terkait dengan Bea Perolehan Hak Atas Tanah dan Bangunan (BPHTB) diatur dalam Peraturan Daerah Kota Padang Nomor 1 Tahun 2011 tentang Bea Perolehan Hak Atas Tanah dan Bangunan. Dalam Peraturan Daerah kota Padang Nomor 1 Tahun 2011 tentang BPHTB yang dimaksud dengan Pajak Daerah yang selanjutnya disebut Pajak adalah kontribusi wajib kepada daerah yang terutang oleh orang pribadi atau badan hukum yang bersifat memaksa berdasarkan Undang-undang, dengan tidak mendapatkan imbalan secara langsung dan digunakan untuk keperluan daerah bagi sebesar-besarnya kemakmuran rakyat.

Sebagai aturan pelaksana Perda Kota Padang Nomor 1 tahun 2011, telah diundangkan Peraturan (Perwako) Padang Nomor 27 Tahun 2016 tentang Sistem dan Prosedur Pemungutan Bea Perolehan Hak Atas Tanah dan Bangunan. Perwako ditujukan kepada Bapenda kota Padang sebagai ketentuan operasional dalam menjalankan tugas pokok dan fungsinya.

Dassollen atau kondisi seharusnya adalah Badan Pendapatan Daerah seharusnya dalam melakukan verifikasi penelitian SSPD berdasarkan nilai NJOP oleh karena dalam Pelaksanaan peralihan hak yang akan dilakukan oleh PPAT terhadap proses Pembagian Hak Bersama para pihak tidak menerima uang/tidak ada transaksi uang. Sedangkan Das Sein atau kenyataannya adalah dimana dalam penerapannya terjadi kesenjangan antara peraturan dan dengan prakteknya terkait verifikasi penelitian SSPD yang tidak mengatur dasar penilaian nilai harga tanah yang dijadikan objek transaksi peralihan hak atas tanah sehingga mengakibatkan adanya ketidakpastian hukum mengenai dasar pengenaan berdasarkan NJOP tanah oleh Dinas Pendapatan Daerah. Bahwa harga pasar tanah tetap menjadi dasar dalam penentuan harga oleh Badan Pendapatan Daerah Kota Padang tentang verifikasi dan hal ini menyebabkan kerancuan terhadap verifikasi dalam proses Peralihan hak akibat pembagian hak bersama dan tentunya hal tersebut menjadi permasalahan bagi para Notaris 
dan PPAT serta bagi wajib dalam bertransaksi.

Berdasarkan latar pemikiran di atas, maka permasalahan yang akan diteliti dapat dirumuskan sebagai berikut: Bagaimana Pemungutan Bea Perolehan Hak Atas dan Bangunan (BPHTB) di Kota Padang?, Bagaimana proses verifikasi harga Tanah dan Bangunan serta kendala dalam Pemungutan BPHTB terhadap Pembuatan Akta Pembagian Hak Bersama (APHB) di Kota Padang?, Apakah upaya Pemerintah Kota Padang dalam kendala Pemungutan BPHTB terhadap Pembuatan Akta Pembagian Hak Bersama (APHB) di Kota Padang?.

\section{METODE PENELITIAN}

Metode pendekatan penelitian yang digunakan oleh peneliti adalah pendekatan yuridis empiris yaitu penelitian yang mengkaji norma hukum yang berlaku dengan fakta yang terjadi di lapangan (Laurensius Arliman S, 2018). Penelitian ini bersifat deskriptif analitis yaitu menggambarkan atau memaparkan dan menjelaskan objek penelitian. Dalam penelitian ini teknik/metode yang digunakan penulis dalam pengumpulan data adalah studi kepustakaan dan wawancara. Jenis data yang digunakan yaitu data primer, data sekunder dengan bahan hukum primer, bahan hukum sekunder, bahan hukum tersier. Lokasi Penelitian di Kantor Badan Pendapatan Daerah (Bapenda) Kota Padang, Kantor Notaris/PPAT Kota Padang. Bahan hukum yang diperoleh dianalisis secara kualitatif.

\section{HASIL DAN PEMBAHASAN}

1. Pemungutan Bea Perolehan Hak Atas Tanah Dan Bangunan (BPHTB) di Kota Padang

Berdasarkan ketentuan Pasal 20 Undang-Undang Nomor 5 Tahun 1960 tentang Peraturan Dasar Pokok-pokok Agraria (UUPA) dijelaskan bahwa kepemilikan hak atas tanah disebabkan adanya peralihan hak dapat terjadi karena adanya perbuatan hukum dan peristiwa hukum. Peralihan hak atas tanah karena perbuatan hukum merupakan suatu tindakan yang dikehendaki oleh para pihak sehingga menimbulkan hak dan kewajiban misalnya jual beli, tukar menukar, hibah, hibah wasiat (Beatrix Benni, 2019).

Terkait tanah yang dibangun oleh Pengembang yang berbadan hukum, kepadanya diberikan dengan status Hak Guna Bangunan dengan jangka waktu 30 tahun sertifikat induk, berlaku sama terhadap sertifikat pecahannya untuk kepentingan pengkaplingan. Status Hak Guna Bangunan tetap melekat pada sertifikat pecahan meskipun sudah beralih haknya ke atas nama Pembeli. (Aflinda Dewi, 2019)

Berdasarkan hasil wawancara dengan Arif Saputra selaku Aparatur Pelaksana dan Pemeriksa Pajak Daerah Kantor Badan Pendapatan Daerah (Bapenda) Kota Padang menyatakan bahwa Penerapan pemungutan BPHTB atas perbuatan hukum peralihan hak atas tanah dan/bangunan oleh Bapenda Kota Padang sebagai fiskus dilaksanakan berdasarkan Perwako Padang Nomor 27 Tahun 2016 
Eka Susanti: Problematika Dalam Pelaksanaan Pemungutan Bea Perolehan Hak Atas...

tentang Sistem dan Prosedur Pemungutan Bea Perolehan Hak Atas Tanah dan Bangunan. Tata cara pemungutan BPHTB yang dilaksanakan Bapenda Kota Padang dilakukan oleh setiap wajib pajak dengan menghitung sendiri BPHTB yang terhutang dengan cara mengalikan tarif dengan NPOP setelah dikurangi NPOPTKP, sebagaimana tertera dalam blanko isian SSPD BPHTB. Berdasarkan Perda Kota Padang Nomor 1 Tahun 2011 tentang BPHTB ditetapkan bahwa tarif pajak yang dikenakan untuk BPHTB adalah sebesar 5\% (lima per seratus) dan NPOP setelah dikurangi NPOPTKP Kota Padang sebesar Rp.60.000.000,- (enam puluh juta rupiah).

Hasil perhitungan sendiri SPPD BPHTB berikut dokumen wajib pajak sebagaimana dimaksud dilakukan penelitian/verifikasi oleh BAPENDA Kota Padang dalam hal ini Kepala Bidang Pendataan dan Penetapan. Penelitian/verifikasi SSPD BPHTB tersebut meliputi:

a. Penelitian/verifikasi atas kebenaran informasi yang tercantum dalam SSPD;

b. Penetitian/verifikasi atas kelengkapan dokumen pendukung SSPD;

c. Penelitian/verifikasi lapangan.

Penelitian/verifikasi SSPD yang dilakukan oleh BAPENDA sebagaimana dimaksud dilakukan dengan tujuan:

1) Mencocokkan Nomor Objek Pajak (NOP) yang dicantumkan dalam SSPD dengan NOP yang tercantum dalam fotokopi SSPT atau bukti pembayaran lainnya;

2) Mencocokkan NJOP bumi permeter persegi yang dicantumkan dalam SSPD dengan NJOP bumi per meter persegi dengan basis data pajak Bumi dan Bangunan Pedesaan dan Perkotaan;

3) Mencocokkan NJOP bangunan per meter persegi yang dicantumkan dalam SSPD dengan NJOP bangunan per meter persegi dengan basis data Pajak Bumi dan Bangunan Pedesaan dan Perkotaan;

4) Meneliti kebenaran penghitungan Pajak terhutang yang meliputi dasar pengenaan

(NPOP/NJOP), NPOPTKP, tarif, pengenaan atas objek tertentu, BPHTB terhutang/yang harus dibayar;

5) Meneliti kebenaran penghitungan BPHTB yang disetor, termasuk besarnya pengurangan yang dihitung sendiri.

Berdasarkan hasil wawancara dengan Irawati selaku Aparatur Pelaksana dan Pemeriksa Pajak Daerah Kantor Badan Pendapatan Daerah (Bapenda) Kota Padang menyatakan bahwa Dokumen yang diserahkan kepada Bapenda Kota Padang berikut dengan formulir SPPD yang telah dihitung, terdiri atas:

a. Fotokopi sertifikat tanah atau bukti kepemilikan lainnya yang telah dilegalisir oleh pejabat yang berwenang (Pejabat Pembuat Akta Tanah/Kepala Badan Pertanahan);

b. Fotokopi Kartu Tanda Penduduk (KTP) bagi wajib Pajak orang 
pribadi, akta pendirian Badan dan atau Kartu Tanda Penduduk Pimpinan Badan;

c. Fotokopi Surat Pemberitahuan Pajak Terhutang Pajak Bumi dan Bangunan (SSPT PBB) tahun berjalan;

d. Fotokopi tanda bukti lunas PBB tahun berjalan dan atau melunasi tunggakan;

e. Foto dan denah lokasi objek pajak;

f. Dalam hal terdapat perbedaan nama yang tercantum dalam SPPT PBB dengan sertifikat tanah, agar melampirkan Surat Keterangan Lurah yang menerangkan bahwa tanah dan atau bangunan yang tercantum dalam SPPT PBB sama dengan tanah yang tercantum dalam sertifikat;

g. Daftar harga rumah yang dikeluarkan oleh developer/ pengembangan perumahan bagi perumahan baru.

2. Proses Verifikasi Harga Tanah dan Bangunan Serta Kendala Dalam Pemungutan BPHTB Terhadap Pembuatan Akta Pembagian Hak Bersama (APHB) Di Kota Padang

\section{A. Proses Verifikasi Harga Tanah dan Bangunan}

Dispenda selaku pelaksanaan pemungutan BPHTB berwenang melakukan pemeriksaan berupa verifikasi terhadap SSPD BPHTB. Dalam pelaksanaannya, faktor yang mendukung pemungutan BPHTB adalah tersedianya sarana dan prasarana yang dibutuhkan, adanya hubungan kerja sama dengan pihak Notaris/PPAT, Badan Pertanahan dan Bank dan jumlah SDM. (Witri, 2016)
Berdasarkan hasil penelitian dengan Jonirson selaku Aparatur Pelaksana dan Pemeriksa Pajak Daerah Kantor Badan Pendapatan Daerah (Bapenda) Kota Padang menyatakan bahwa Bapenda dalam melakukan peneliitan verifikasi SSPD menggunakan formulir kertas kerja penelitian/veritikasi, dengan unsur-unsur yang diteliti/diverifikasi sebagai berikut:

a. NOP Pajak Bumi dan Bangunan Pedesaan dan Perkotaan; 2018. Petugas peneliti mencocokkan NOP yang dicantumkan dalam SSPD dengan NOP yang tercantum dalam fotokopi SPPT atau bukti pembayaran Pajak Bumi dan Bangunan Pedesaan dan Perkotaan lainnya;

b. Besarnya NJOP tanah (bumi) dan atau bangunan per meter persegi; Petugas peneliti mencocokkan NJOP tanah (bumi) dari atau Bangunan Pedesaan dan Perkotaan;

c. Penghitungan NJOP;

d. Penghitungan BPHTB, terutama untuk meneliti kebenaran:

1) NPOP;

NPOP diisi dengan harga transaksi/Nilai Pasar, apabila harga transaksi/nilai pasar tidak diketahui atau lebih kecil dan pada NJOP maka NPOP diisi dengan NJOP; Kecuali perolehan hak karena lelang apabila harga transaksi yang tercantum dalam risalah lelang lebih kecil dan pada NJOP maka NPOP diisi dengan NJOP;

2) NPOPTKP;

3) BPHTB yang terutang; 
Eka Susanti: Problematika Dalam Pelaksanaan Pemungutan Bea Perolehan Hak Atas...

4) BPHTB yang harus dibayar.

Dalam hal diperlukan penelitian/verifikasi lapangan, Bapenda menunjuk pejabat dengan menerbitkan surat tugas untuk melakukan penelitian/verifikasi lapangan, dengan tujuan untuk mengetahui kebenaran harga transaksi/nilai pasar yang dicantumkan oleh wajib pajak.

SSPD yang sudah dilakukan penelitian/verifikasi dikembalikan kepada wajib pajak dilengkapi dengan salinan Kertas Kerja Penelitian. Dalam hal hasil penelitian/verifikasi tidak ada koreksi, Kepala bidang Pendataan dan Penetapan menerbitkan lembaran persetujuan SSPD sebagai syarat pembayaran BPHTB kepada Bank persepsi yang ditunjuk. Dalam hal hasil penelitian/verifikasi ada koreksi dan disetujui oleh wajib pajak, maka SSPD diperbaiki oleh wajib pajak sesuai dengan kertas kerja penelitian/ verifikasi. Setelah SSPD diperbaiki oleh wajib pajak, wajib pajak wajib mengembalikannya kepada Kepala Bidang Pendataan dan Penetapan untuk diterbitkan lembar persetujuan sebagai syarat pembayaran BPHTB kepada Bank Persepsi yang ditunjuk.

Wajib pajak yang tidak menyetujui hasil kertas kerja penelitian/ verifikasi sebagaimana dimaksud dapat memohon secara tertulis hanya 1 (satu) kali kepada Kepala Badan melalui Bidang Pendataan dan Penetapan untuk dilakukan penelitian ulang dengan disertai:

a. Data pendukung dan keterangan harga transaksi/nilai dan pejabat di wilayah objek pajak sebagai pertimbangan dalam kertas kerja Penelitian;

b. Surat pemyataan wajib pajak yang menyatakan kejujuran harga transaksi sesuai kondisi sebenarnya.

Setelah wajib pajak mengajukan penelitian ulang, Kepala Dinas wajib mengabulkan seluruh SSPD dan kelengkapan administrasi permohonan wajib pajak berdasarkan hasil penelitian ulang, wajib pajak membayar BPHTB yang terhutang kepada Bank Persepsi yang ditunjuk. Pembayaran BPHTB melalui pembayaran Modul Penerimaan Negara (MPN). Sistem ini dilaksanakan untuk pembayaran semua jenis pajak, termasuk diantaranya yaitu BPHTB secara online. Dengan sistem ini, maka semua Bank atau tempat pembayaran yang mempunyai fasilitas online bisa ditunjuk sebagai persepsi untuk menerima pembayaran BPHTB.

Apabila pembayaran telah dilakukan, wajib pajak menyerahkan bukti pembayarannya kepada Kepala Sub Bagian Pelayanan Informasi Pendapatan. Kepala Sub Bagian Pelayanan Informasi Pendapatan meneruskan kepada Kepala Bidang Pendataan dan Penetapan untuk ditandatangani dan di legalisasi. Kepada Bidang Pendataan dan Penetapan meneruskan kepada Kepala Sub Bagian Pelayanan Informasi Pendapatan untuk selanjutnya diserahkan kepada wajib pajak.

Setelah SSPD-BPHTB divalidasikan oleh Bapenda dan dilegalisasi atau ditandatangani, barulah wajib pajak dapat 
melakukan peralihan hak atas tanah melalui pembagian Hak Bersama di hadapan pejabat yang berwenang (PPAT). Apabila SSPDB PHTB belum ditandatangani oleh Bidang Pendataan dan Penetapan Bapenda Kota Padang, maka penandatanganan akta peralihan hak di hadapan PPAT/Notaris juga belum dapat dilakukan, PPAT/Notaris dilarang untuk menandatangani akta peralihan hak sebelum wajib pajak melunasi BPHTB sebagaimana mestinya dan hanya dapat menandatangani akta peralihan hak tersebut setelah wajib pajak menyerahkan bukti pembayaran pajak kepada PPAT/Notaris yang bersangkutan.

Mekanisme pemungutan BPHTB yang dilakukan oleh Bapenda berdasarkan Perwako Padang Nomor 27 Tahun 2016 tersebut berbeda dengan mekanisme pemungutan BPHTB sebagaimana diatur dalam Perda Kota Padang Nomor 1 Tahun 2011 Tentang BPHTB. Pada Perda Kota Padang Nomor 1 Tahun 2011 tentang BPHTB, wajib pajak atau kuasa menghitung sendiri pajak terhutang dengan menggunakan SSPD dan langsung membayar kepada bank persepsi. Hasil perhitungan pajak terhutang yang telah dibayar wajib pajak dilaporkan tanpa mendasarkan kepada Bapenda Kota Padang untuk dilakukan penelitian. Penelitian sebagaimana dimaksud hanya dimaksudkan untuk antara lain:

1. Memastikan bahwa pajak telah dibayar/disetor ke kas daerah;

2. Dasar pengenaan yang digunakan sudah benar;
3. PBB atas objek pajak sudah lunas atau tidak ada tunggakan.

Berdasarkan hasil wawancara dengan Jonirson selaku Aparatur Pelaksana dan Pemeriksa Pajak Daerah Kantor Badan Pendapatan Daerah (Bapenda) Kota Padang menyatakan sistem pemungutan pajak yang diterapkan oleh Bapenda Kota Padang sebagaimana juga diatur dalam Perwako Padang Nomor 27 Tahun 2016 berbeda dengan sistem pemungutan pajak yang diatur Perda Kota Padang Nomor 1 Tahun 2011, yaitu Semiself Assessment System. Bapenda Kota Padang diberikan kewenangan untuk menilai memverifikasi SPPD BPHTB pajak terhutang yang telah dihitung sendiri oleh wajib pajak. Hasil penilaian/verifikasi oleh Bapenda tersebut menentukan nilai pajak terhutang wajib pajak. Dapat diketahui bahwa dengan adanya perhitungan sendiri oleh wajib pajak dan ketetapan pajak berdasarkan hasil penelitian/verifikasi Bapenda, sistem pemungutan tersebut telah dikonftrniasi dan dibenarkan oleh Bapenda Kota Padang berdasarkan hasil penelitian penulis di Bapenda Kota Padang. Dapat diketahui bahwa sistem pemungutan pajak BPHTB yang dianut dalam Perda Kota Padang Nomor 1 Tahun 2011 dengan Perwako Padang Nomor 27 Tahun 2016 tidak koheren.

Dalam hal peralihan hak atas tanah dan atau bangunan akibat hukum Pembagian Hak Bersama, besarnya nilai pajak terhutang yang dihitung sendiri oleh wajib pajak diatur dalam Pasal 5 ayat (2) huruf a Perda Kota Padang yaitu dikenakan berdasarkan dan Nilai Pasar. 
Eka Susanti: Problematika Dalam Pelaksanaan Pemungutan Bea Perolehan Hak Atas...

\begin{tabular}{|c|c|}
\hline $\begin{array}{l}\text { Tingginya harga pasar yang } \\
\text { ditetapkan Bapenda Kota Padang, } \\
\text { dianggap tidak sesuai dengan tujuan dan } \\
\text { pemeriksaan atau verifikasi yaitu } \\
\text { mencocokkan NOP yang tertera dalam } \\
\text { formulir SSPD-BPHTB dengan NJOP } \\
\text { yang ada dalam Pajak Bumi dan } \\
\text { Bangunan (PBB). Penelitian kebenaran } \\
\text { data peralihan hak atas tanah dan } \\
\text { bangunan yang tercantum dan tertera } \\
\text { dalam SSPD-BPHTB merupakan syarat } \\
\text { yang harus dilakukan sebelum Bidang } \\
\text { Pendataan dan Penetapan menandatangani } \\
\text { SSPD-BPHTB. Apabila SSPD-BPHTB } \\
\text { belum ditanda-tangani oleh Bidang } \\
\text { Pendataan dan Penetapan Bapenda Kota } \\
\text { Padang, maka penandatanganan akta } \\
\text { peralihan hak di hadapan PPAT/Notaris } \\
\text { juga belum dapat dilakukan, }\end{array}$ & $\begin{array}{l}\text { perhitungan BPHTB belum bisa } \\
\text { diterapkan. } \\
\text { Dikaitkan dengan pelaksanaan } \\
\text { pemungutan BPHTB di Kota Padang, } \\
\text { seharusnya dasar pemungutan pajak } \\
\text { BPHTB atas peralihan hak atas } \\
\text { pembagian Hak bersama sebagaimana } \\
\text { ditetapkan dalam Perwako Nomor } 27 \\
\text { Tahun } 2016 \text { substansinya harus sama } \\
\text { dengan Perda Kota Padang Nomor } 1 \\
\text { Tahun } 2011 \text { yaitu ditetapkan berdasarkan } \\
\text { harga transaksi. Seharusnya institusi } \\
\text { terkait (Bapenda) memahami hal tersebut } \\
\text { dengan memperhatikan dampak } \\
\text { hukumnya bagi masyarakat, bukan hanya } \\
\text { untuk mencapai tujuan meningkatkan } \\
\text { pendapatan asli daerah semata, sehingga } \\
\text { efektifitas dan peraturan perundang- } \\
\text { undangan belum dapat tercapai. }\end{array}$ \\
\hline
\end{tabular}
PPAT/Notaris dilarang untuk menandatangani akta peralihan hak sebelum wajib pajak melunasi BPHTB sebagaimana mestinya dan hanya dapat menandatangani akta peralihan hak tersebut setelah wajib pajak menyerahkan bukti pembayaran pajak kepada PPAT/Notaris yang bersangkutan.

Dalam pemungutan BPHTB di Kota Padang belum sepenuhnya berjalan sesuai dengan ketentuan perundang-undangan yang berlaku. Ketentuan mengenai dasar pengenaan pajak adalah NPOP. NPOP sebagaimana disebutkan di dalam Pasal 5 ayat (2) huruf a Perda Kota Padang Nomor 1 Tahun 2011 ditentukan berdasarkan harga transaksi. Oleh karena itu di Kota Padang penilaian dengan menentukan NPOP atas peralihan hak berdasarkan harga pasar sebagai dasar

\section{B. Kendala Dalam Pemungutan Bea Perolehan Hak atas Tanah dan Bangunan (BPHTB) di Kota Padang}

Berdasarkan hasil wawancara dengan Arif Saputra selaku Aparatur Pelaksana dan Pemeriksa Pajak Daerah Kantor Badan Pendapatan Daerah (Bapenda) Kota Padang menyatakan bahwa hambatan dalam pemungutan BPHTB di kota Padang terbagi atas 2 yaitu:

a. Kendala Yuridis

1) Perda Kota Padang Nomor 1 Tahun 2011 Tentang BPHTB dengan Perwako Padang Nomor 27 Tahun 2016 tentang Sistem dan Prosedur Pemungutan Bea Perolehan Hak Atas Tanah dan Bangunan 
Salah satu kendala yang menghambat jalannya pemungutan pajak BPHTB di Kota Padang adalah adanya beberapa perbedaan aturan dalam Perda Kota Padang Nornor I Tahun 2011 dengan Perwako Nomor 27 Tahun 2016, yang menjadi landasan operasional Bapenda dalam menjalankan tugas pokok dan fungsinya, diantaranya adalah perbedaan sistem pemungutan pajak. Pada Pasal 13 Perda Kota Padang Nomor 1 Tahun 2011 disebutkan bahwa sistem pemungutan pajak yang diterapkan adalah Self Assessment System, dimana wajib pajak diberi kepercayaan untuk menghitung dan membayar sendiri pajak yang terutang dengan menggunakan SSPD dan melaporkannya tanpa mendasarkan kepada Bapenda. Dalam ketentuan ini Bapenda bersifat pasif hanya menerima laporan pajak terhutang dan SSPD yang telah dihitung dan telah dibayar oleh wajib pajak dan memastikan bahwa pajak telah dibayar/disetor ke kas daerah, dasar pengenaan yang digunakan sudah benar, dan PBB atas objek pajak sudah lunas atau tidak ada tunggakan. Pada Pasal 2 angka (2) dan (3) Perwako Nomor 27 Tahun 2016 sistem pemungutan BPHTB yang digunakan adalah Semiself Assessment System, dimana wajib pajak mengisi sendiri blangko SSPDBPHTB dan menyerahkannya kepada Bapenda untuk diteliti/verifikasi. Wajib pajak tidak bisa secara langsung membayar kecuali setelah dikeluarkannya ketetapan hasil persetujuan verifikasi pajak oleh Bapenda.

Bapenda Kota Padang menentukan NPOP-BPHTB yang akan dikenakan tarif pajak dengan dasar pengenaan harga transaksi/ harga pasar, sebagaimana diatur dalam Pasal 6 angka 3 huruf $d$ Perwako Padang Nomor 27 Tahun 2016. Pada Perda Kota Padang Nomor 1 Tahun 2011 dasar pengenaan BPHTB juga ditentukan atas dua bentuk, yaitu harga transaksi/harga pasar, namun pada Perda Kota Padang Nomor 1 Tahun 2011, bentuk peralihan yang dikenakan atas harga transaksi dan bentuk peralihan hak atas tanah dan/atau bangunan yang dikenakan berdasarkan harga pasar diatur jelas. Pengaturan bentuk peralihan hak tersebut tidak ditemukan di dalam Perwako Padang Nomor 27 Tahun 2016. Tanpa adanya pengaturan rinci, berakibat Bapenda menjadi penentu kapan NPOP ditetapkan dengan harga transaksi dan kapan ditetapkan dengan harga pasar.

2) Perda Kota Padang Nomor 1 Tahun 2011 tentang BPHTB dengan Perwako Padang Nomor 27 Tahun 2016 tentang Sistem dan Prosedur Pemungutan BPHTB dan dengan Peraturan Pemerintah Nomor 34 Tahun 2016 Tentang Pajak Penghasilan atas Penghasilan dari Pengalihan Hak Atas Tanah dan/atau Bangunan 
Eka Susanti: Problematika Dalam Pelaksanaan Pemungutan Bea Perolehan Hak Atas...

Hambatan yang sering terjadi dalam pemungutan BPHTB di Kota Padang adalah pada saat penilaian/verifikasi untuk menentukan dasar pengenaan NPOP peralihan hak atas tanah dan/atau bangunan akibat hukum jual beli. Dasar pengenaan NPOP dilandasi oleh Pasal 5 angka (2) Perda Kota Padang Nomor 1 Tahun 2011 tentang BPHTB ditentukan berdasarkan harga transaksi. Dalam Pasal 6 angka (3) huruf d Perwako Padang Nomor 27 Tahun 2016 tentang Sistem dan Prosedur Pemungutan BPHTB tidak disebutkan dasar pengenaan NPOP akibat perbuatan hukum Pembagian Hak bersama, hanya disebutkan NPOP ditentukan berdasarkan harga transaksi/ harga pasar, akibatnya dalam melakukan penilaian/verifikasi Bapenda lebih menekankan penilaian NPOP dan harga pasar, yang lebih tinggi dan harga transaksi yang disepakati para pihak yang melakukan perbuatan hukum peralihan Hak berdasarkan Pembagian Hak Bersama.

Setelah wajib pajak menyetujui NPOP yang telah ditetapkan Bapenda dan telah selesai membayar kewajiban pajak setelah dikalikan tarif dan telah di validasi, ternyata wajib pajak mesti harus membayar kekurangan pajak karena pada saat wajib pajak melakukan pembayaran pajak penghasilan $(\mathrm{PPh})$ bagi pihak yang melepaskan kepada Kantor Pelayanan Pajak Pratama (KPP
Pratama) Kota Padang, NPOP yang akan ditetapkan oleh KPP PrataMa didasarkan kepada harga pasar, sebagaimana diatur dalam Pasal 2 ayat (2) huruf e PP Nomor 34 Tahun 2016 yang mana penetapan harga pasar oleh fiskus yang bersangkutan lebih tinggi dari penetapan harga pasar Bapenda. Hambatan yang muncul adalah nilai penetapan NPOP antara BPHTB dengan $\mathrm{PPh}$ harus sama agar PPAT sebagai pejabat yang berwenang dan Instansi yang terkait dengan Pertanahan (Badan Pertanahan Nasional) dapat menentukan harga transaksi yang akan dipakai. Badan Pertanahan Nasional (BPN) yang mengadministrasikan masalah hak atas tanah dan pemerintah Kabupaten/Kota mempunyai tugas pokok dan fungsi yang berbeda namun pada dasarnya mempunyai sasaran yang sama terutama dalam pemberian pelayanan dalam masyarakat di bidang pertanahan, namun BPN tidak dapat memproses peralihan hak atas tanah dengan kondisi urusan perpajakan yang tidak sama antara BPHTB dengan PPh.

Lebih kecilnya penetapan NPOP dan Bapenda, wajib pajak harus menyesuaikan nilai penetapan NPOP dengan nilai NPOP yang ditetapkan oleh KPP Pratama Kota Padang, dengan akibat hukum terjadinya kekurangan bayar pajak terhadap BPHTB. Tidak adanya koordinasi antar instansi dan perbedaan aturan 
dalam penetapan NPOP yang akan dikenakan pajak tersebut menimbulkan keresahan dan membebankan masyarakat. Dan kasus tersebut, dapat dinilai bahwa penilaian NPOP BPHTB yang akan dikenakan pajak jadi bergantung kepada penetapan NPOP PPh yang ditetapkan oleh KPP Pratama Kota Padang.

3) KUHP Perdata Pasal 1338 dan Pasal 1320 dengan Perwako Padang Nomor 27 Tahun 2016 Tentang Sistem dan Prosedur Pemungutan Bea Perolehan Hak Atas Tanah dan Bangunan

Berdasarkan Pasal 5 ayat (2) huruf a Perda Kota Padang Nomor 1 Tahun 2011 Tentang BPHTB dasar pengenaan NPOP atas peralihan hak atas tanah dan bangunan karena Akta Pembagian Hak Bersama yaitu dikenakan berdasarkan dan harga transaksi. Ketentuan Pasal tersebut sesuai dengan asas konsensualime yang menjiwai hukum perjanjian yang diatur dalam Pasal 1338 Kitab Undang-Undang Hukum Perdata (KUHPerdata), maka perjanjian itu lahir sejak adanya kata sepakat, yaitu saat nilai transaksi disepakati para pihak. Dalam suatu perjanjian jual beli, sepakatnya para pihak mengenai barang dan harga adalah merupakan syarat sahnya perjanjian sebagaimana diatur dalam Pasal 1320 KUHPerdata. Oleh karena itu apabila para pihak (penjual dan pembeli) menghadap kepada PPAT/Notaris dan memberikan keterangan mengenai barang dan harga yang mereka sepakati sebagai obyek Pembagian Hak Bersama, maka keterangan itulah yang dianggap sebagai NPOP yang sebenarnya, dan untuk lebih menguatkan keterangan para pihak tersebut dapat dibuktikan dengan adanya kuitansi yang dibuat oleh Para Pihak. Metode seperti itu tidak bertentangan dengan UndangUndang dan Perda Kota Padang yang mengatur tentang BPHTB dengan syarat nilainya tidak dibawah nilai NJOP yang telah ditetapkan oleh Bapenda.

Adanya ketentuan Pasal 6 ayat (3) huruf d Perwako Padang tentang Sistem dan Prosedur Pemungutan Bea Perolehan Hak Atas Tanah dan Bangunan, perhitungan penetapan NPOP yang akan dikenakan tarif pajak dilakukan dengan dua pilihan yaitu berdasarkan Nilai Transaksi atau Nilai Pasar, sehingga dalam pelaksanaan pemungutan pajak sering terjadi perbedaan penilaian pajak terhutang antara wajib pajak dengan Bapenda Kota Padang. Bapenda Kota Padang dalam melakukan penilaian/verifikasi lebih menekankan perhitungan pajak terhutang BPHTB dan harga pasar, berdasarkan penelitian pejabat instansi tersebut di lapangan. Akibat hukum berdampak pada besarnya NPOP yang akan dikenakan pajak apabila nilai harga transaksi yang telah disepakati para pihak di bawah harga pasar. Hal ini tidak sesuai 
Eka Susanti: Problematika Dalam Pelaksanaan Pemungutan Bea Perolehan Hak Atas...

dengan asas kebebasan berkontrak dan syarat sahnya perjanjian apabila pihak ketigalah yang menentukan harga transaksi yang telah disepakati para pihak sebagaimana diatur dalam Pasal 1338 dan Pasal 1320 KUHPerdata.

b. Kendala Non Yuridis

Berdasarkan data yang penulis peroleh dari Arif Saputa selaku Pelaksana dan Pemeriksa Pajak Daerah Kantor Badan Pendapatan Daerah (Bapenda) Kota Padang, penerimaan daerah yang berasal dan penerimaan BPHTB selama 6 (enam) tahun terakhir berada di atas rencana anggaran. Namun demikian masih ada beberapa hambatan yang dihadapi, yaitu adanya upaya untuk menghindari pajak dengan tidak menyampaikan Nilai Perolehan Hak atas Tanah dan Bangunan yang sebenarnya, sehingga dasar pengenaan pajak bukan lagi NPOP melainkan NJOP.

Hambatan yang ditemukan di lapangan adalah sebagai berikut:

1) Ketidak tahuan wajib pajak tentang BPHTB. Mereka baru mengetahuinya setelah akan melakukan .peralihan hak dan mendapatkan penjelasan dari PPAT/Notaris.

2) Upaya menghindari pajak juga merupakan kendala yang sangat umum terjadi, yaitu apabila harga pasar atau nilai transaksi lebih tinggi dan NJOP, mereka akan menyampaikan bahwa harga transaksi sesuai dengan NJOP. Demikian juga apabila NPOP lebih rendah dan NJOP, masyarakat akan berusaha menghindarinya. Sehingga dasar pengenaan BPHTB tidak lagi NPOP, melainkan NJOP.

3) Adanya wajib pajak yang tidak melaporkan perbuatan hukum yang mengakibatkan peralihan hak, ke Kantor Pelayanan Pajak Bumi dan Bangunan, dengan menyampaikan SSB lembar ketiga.

\section{Upaya Pemerintah Kota Padang Dalam Kendala Pemungutan BPHTB Terhadap Pembuatan Akta Pembagian Hak Bersama (APHB) Di Kota Padang}

Berdasarkan hasil penelitian yang penulis temukan di lapangan dalam Prakteknya di lapangan pemungutan BPHTB dilakukan oleh Bapenda Kota Padang berdasarkan Perwako Nomor 27 Tahun 2016 yaitu Bapenda Kota Padang menentukan pajak BPHTB yang harus disetorkan, Bapenda Kota Padang menentukan berdasarkan letak tanah atau zona tanah, bentuk bangunan, hal tersebut dilakukan oleh Bapenda Kota Padang guna meningkatkan pendapatan daerah Kota Padang.

Penulis berpendapat bahwa harus adan koordinasi antara instansi dan pejabat yang terkait dalam melakukan tugasnya terkait peralihan hak atas tanah dan bangunan, seperti Bapenda Kota Padang, KPP Pratama kota Padang, Badan Pertanahan Nasional (BPN) Kota Padang dan Pejabat Pembuat Akta Tanah 
(PPAT), agar terciptanya kepastian hukum dalam urusan administratif dan memberikan kemudahan bagi masyarakat dalam melakukan kegiatan hukum peralihan hak atas tanah dan bangunan. Bidang Pendataan dan penetapan Dinas Pendapatan Kota Padang selaku pihak yang terkait dalam pelaksanaan agar memberikan sosialisasi bagi masyarakat agar masyarakat memiliki pemahaman hukum terkait peralihan hak atas tanah dan bangunan khususnya BPHTB dan mempermudah proses pemeriksaan atau verifikasi BPHTB, agar dapat meningkatkan kesadaran hukum bagi masyarakat dalam membayar pajak.

Acuan yang jelas sangat diperlukan dalam menentukan NJOP atas tanah dan bangunan yang akan dikenakan tarif pajak. Apabila penetapan dilakukan berdasarkan harga pasar, maka harga pasar segera ditetapkan dengan Surat Penetapan oleh Dinas Pendapatan Daerah kota Padang atau Perda oleh pemerintah Kota Padang, agar wajib pajak dan pihak terkait lainnya mendapatkan kepastian tentang penentuan harga pasar yang ditetapkan oleh Badan Pendapatan kota Padang dalam melakukan pemeriksaan atau verifikasi BPHTB. Apabila Penetapan NPOP ditentukan berdasarkan NJOP, pemerintah (BAPENDA), harus segera merevisi NJOP yang tertera dalam SPPT BPP yang sesuai dengan nilai standar bagi masyarakat dan juga tidak mengurangi nilai pendapatan asli bagi daerah kota Padang.

\section{SIMPULAN}

Berdasarkan uraian di atas, maka penulis menarik kesimpulan sebagai berikut:

1. Pemungutan Bea Perolehan Hak Atas Tanah dan Bangunan (BPHTB) di Kota Padang yaitu dilaksanakan berdasarkan Perwako Padang Nomor 27 Tahun 2016 Tentang Sistem dan Prosedur Pemungutan Bea Perolehan Hak Atas Tanah dan Bangunan. Tata cara pemungutan BPHTB yang dilaksanakan Bapenda Kota Padang dilakukan oleh setiap wajib pajak dengan menghitung sendiri BPHTB yang terhutang dengan cara mengalikan tarif dengan NPOP setelah dikurangi NPOPTKP, sebagaimana tertera dalam blanko isian SSPD BPHTB.

2. Proses Verifikasi Harga Tanah dan Bangunan Dalam Pemungutan BPHTB Terhadap Pembuatan Akta Pembagian Hak Bersama (APHB) Di Kota Padang yaitu menggunakan formulir kertas kerja penelitian/veritikasi, dengan unsurunsur yang diteliti/diverifikasi seperti NOP Pajak Bumi dan Bangunan Pedesaan dan Perkotaan, Besarnya NJOP tanah (bumi) dan atau bangunan permeter persegi, Penghitungan NJOP, Penghitungan BPHTB, terutama untuk meneliti kebenaran, NPOP, NPOPTKP, BPHTB yang terutang, BPHTB yang harus dibayar. Kemudian kendala yang timbul dalam Pemungutan Bea Perolehan Hak atas Tanah dan 
Eka Susanti: Problematika Dalam Pelaksanaan Pemungutan Bea Perolehan Hak Atas...

Bangunan (BPHTB) di Kota Padang yaitu berupa hambatan yutridis diantaranya Perda Kota Padang Nomor 1 Tahun 2011 Tentang BPHTB dengan Perwako Padang Nomor 27 Tahun 2016 tentang Sistem dan Prosedur Pemungutan Bea Perolehan Hak Atas Tanah dan Bangunan, Perda Kota Padang Nomor 1 Tahun 2011 tentang BPHTB dengan Perwako Padang Nomor 27 Tahun 2016 tentang Sistem dan Prosedur Pemungutan BPHTB dan dengan Peraturan Pemerintah Nomor 34 Tahun 2016 Tentang Pajak Penghasilan atas Penghasilan dari Pengalihan Hak Atas Tanah dan/atau Bangunan, KUHP Perdata Pasal 1338 dan Pasal 1320 dengan Perwako Padang Nomor 27 Tahun 2016 Tentang Sistem dan Prosedur Pemungutan Bea Perolehan Hak Atas Tanah dan Bangunan serta hambatan non yuridis berupa ketidaktahuan wajib pajak tentang BPHTB, Upaya menghindari pajak dan Adanya wajib pajak yang tidak melaporkan perbuatan hukum yang mengakibatkan peralihan hak, ke Kantor Pelayanan Pajak Bumi dan Bangunan, dengan menyampaikan SSB lembar ketiga.

3. Upaya Pemerintah Kota Padang Dalam Kendala Pemungutan Bphtb Terhadap Pembuatan Akta Pembagian Hak Bersama (APHB) Di Kota Padang yaitu pemungutan BPHTB dilakukan oleh Bapenda Kota Padang berdasarkan Perwako Nomor 27 Tahun 2016 yaitu Bapenda
Kota Padang menentukan pajak BPHTB yang harus disetorkan, Bapenda Kota Padang menentukan berdasarkan letak tanah atau zona tanah, bentuk bangunan, hal tersebut dilakukan oleh Bapenda Kota Padang guna meningkatkan pendapatan daerah Kota Padang.

\section{DAFTAR PUSTAKA}

Aflinda Dewi, (2019). Peningkatan Hak Guna Bangunan Rumah Tinggal Dibebani Hak Tanggungan Menjadi Hak Milik Di Atas Hak Pengelolaan. Jurnal Cendikia Hukum, 5 (1), 18-31.

Beatrix Benni, (2019). Pembuatan Akta Pembagian Hak Bersama Dalam Peralihan Tanah Karena Pewarisan Di Kota Bukittinggi. Jurnal Cendikia Hukum, 5 (1), 65-76.

Budi Ispriyarso, (2018). Penggunaan Peraturan Bupati Untuk Mengatur Harga Tanah Dalam Pengenaan Bea Perolehan Hak Katas Tanah dan Bangunan. Administrative Law \& Governance Journal, 1 (4), 363370 .

Eko Puji Hartono, (2018). Peranan PPAT Dalam Pembuatan Akta Peralihan Hak Atas Tanah Dan/Atau Bangunan Bekas Hak Milik Adat Berkaitan Dengan Pembayaran Bea Perolehan Hak Atas Tanah dan/atau Bangunan. Jurnal Akta, 5 (1), 159166.

Ilyas, Wirawan. B, Richard. 2013, Hukum Pajak Teori, Analisis dan Perkembangannya, Salemba Empat, Jakarta. 
Intifada Atin Nisya, (2019). Pertanggungjawaban Pidana Atas Penyalahgunaan Pembayaran Bea Perolehan Hak Atas Tanah dan Bangunan (BPHTB) oleh pejabat pembuat AKTA tanah (PPAT), Jurnal Hukum Bisnis, 3 (1), 88-106)

Laurensius Arliman S, (2018). Peranan Metodologi Penelitian Hukum Di Dalam Perkembangan Ilmu Hukum Di Indonesia, Soumatera Law Review, 1 (1).

Mahdi Syahbandir, (2016). Peranan Pajak Bea Perolehan Hak Atas Tanah Dan Bangunan Untuk Meningkatkan Pendapatan Asli Daerah Kabupaten Pidie. Kanun Jurnal Ilmu Hukum, 18 (2), 299-318.

Marihot Pahala Siahaan, 2003, Bea Perolehan Hak Atas Tanah Dan Bangunan Teori Dan Praktek,Edisi I Cet. I, PT. Raja Grafindo, Jakarta.

Marlon Gustia, (2016). Penerapan Hukum Pengenaan Bea Perolehan Hak Atas Tanah dan Bangunan (BPHTB). Jurnal Ius, 4 (1),96-108.

Rochmat Soemitro, 2004, Asas dan Dasar Perpajakan I, Edisi revisi, Refika Aditama, Bandung.

Suryanto, (2018). Analisis Potensi Bea Perolehan Hak Atas Tanah Dan Bangunan Sebagai Salah Satu Pajak Daerah. Jurnal Pemikiran dan Penelitian Administrasi Bisnis dan Kewirausahaan, 3 (3), 273-281.
Wa Ode Nurfitria, (2017). Analisis Efektifitas dan Kontribusi Penerimaan Bea Perolehan Hak Atas Tanah dan Bangunan Terhadap Pendapatan Asli Daerah di Dinas Pendapatan Daerah Kota Jayapura. Jurnal Manajemen dan Akuntansi, 5 (1), 99-105.

Windi, (2015). Analisis Dasar Pengenaan dan Kontribusi Bea Perolehan Hak Atas Tanah dan Bangunan Terhadap Pendapatan Asli Daerah Kota Ternate. Jurnal Emba, 3 (4), 334344.

Wirawan B. Ilyas, 2004, Richard Burton, Hukum Pajak, Edisi Revisi, Salemba Empat, Jakarta.

Witri, (2016). Analisis Pelimpahan Bea Perolehan Hak Atas Tanah dan Bangunan (BPHTB) Kepada Pemerintah Daerah Terhadap Pendapatan Asli Daerah (PAD) (Studi Pada Dinas Pendapatan Daerah Kabupaten Bangkalan). Jurnal Perpajakan, 9 (1), 1-9. 